\title{
GAMBARAN KARAKTERISTIK DAN PENYEBAB PENCABUTAN GIGI SULUNG DI PUSKESMAS PANIKI BAWAH KOTA MANADO PADA TAHUN 2012
}

\author{
${ }^{1}$ Dwi Nur Rakhman \\ ${ }^{2}$ Benedictus S. Lampus \\ ${ }^{3} \mathrm{Ni}$ Wayan Mariati \\ ${ }^{1}$ Kandidat Skripsi Program Studi Pendidikan Dokter Gigi Fakultas Kedokteran \\ ${ }^{2}$ Bagian Ilmu Kesehatan Masyarakat Fakultas Kedokteran \\ ${ }^{3}$ Bagian Ilmu Kedokteran Gigi Dasar Program Studi Pendidikan Dokter Gigi \\ Juniversitas Sam Ratulangi Manado \\ Email:dwi.13rakhman@gmail.com
}

\begin{abstract}
Primary tooth extraction is a common action in dental clinic. There are many reasons for tooth extraction for example periodontal problem that damaged teeth could not be treated with pulp capping or endodontic treatment. Another reason for tooth extraction is orthodontic treatment that require tooth extraction. Some traumatic injury can be considered as a reason for tooth extraction. The purpose of this research is to know description of characteristics and reasons of primary tooth extraction in was Puskesmas Paniki Bawah Manado on 2012. This was descriptive study with retrospective approach. Data was collected are secondary data from all inform consent for primary tooth extraction in was Puskesmas Paniki Bawah Manado on 2012 with total 122. The result based on age show that in age $2-4$ there was 1 extraction $(0,81 \%)$, age $5-9$ there was 105 extraction $(86,06 \%)$, whereas age $10-14$ there was 16 extraction $(13,3 \%)$. Based on the gender, 59 extraction are men $(48,36 \%)$ whereas 63 extraction are women $(51,64 \%)$. Based on the reasons of extraction there are 3 major reasons that is caries, persistent and mobility. Caries was the most common reason for extraction with 70 case $(57,37 \%)$, another reason are mobility with 38 case (31,14\%) and persistent with 14 case $(11,49 \%)$.
\end{abstract}

Keywords: characteristic, reasons of tooth extraction, primary tooth

\begin{abstract}
Abstrak: Pencabutan gigi sulung merupakan tindakan yang umum dilakukan di poli gigi. Terdapat banyak penyebab dilakukannya pencabutan gigi seperti adanya masalah periodontal dimana gigi yang rusak sudah tidak dapat dirawat dengan perawatan pulpa atau perawatan saluran akar. Penyebab lain dilakukannya pencabutan gigi ialah akan dilakukannya perawatan ortodonti yang mengharuskan dilakukannya pencabutan gigi. Adanya cedera traumatik juga dapat dipertimbangkan sebagai salah satu penyebab umum dilakukannya pencabutan gigi. Tujuan penelitian ini ialah untuk mengetahui gambaran karakteristik dan penyebab pencabutan gigi sulung di Puskesmas Paniki Bawah kota Manado pada tahun 2012. Penelitian ini bersifat deskriptif dengan pendekatan retrospektif. Data yang diambil merupakan data sekunder berupa seluruh kartu status pasien pencabutan gigi sulung pada tahun 2012 yang berjumlah total 122. Hasil penelitian berdasarkan usia menunjukan pada usia $2-4$ tahun terdapat 1 pencabutan $(0,81 \%)$, usia $5-9$ tahun terdapat 105 pencabutan (86,06\%) sedangkan usia 10-14 tahun terdapat 16 pencabutan (13,13\%). Berdasarkan jenis kelamin, laki-laki berjumlah 59 anak (48,36\%) sedangkan perempuan berjumlah 63 anak (51,64\%). Berdasarkan penyebab pencabutan gigi diketahui terdapat tiga penyebab pencabutan gigi yaitu karies, mobilitas, dan persistensi gigi. Dari ketiga penyebab tersebut, karies gigi merupakan penyebab terbanyak dengan total 70 pencabutan gigi ( 57,37\%). Penyebab lainnya yaitu mobilitas sebanyak 38 gigi $(31,14 \%)$ dan persistensi sebanyak 14 gigi (11,49\%).
\end{abstract}

Kata kunci: karakterisktik, penyebab pencabutan, gigi sulung 
Berbagai usaha perawatan gigi baik gigi sulung maupun gigi permanen telah banyak dilakukan. Hal ini disebabkan gigi geligi memiliki fungsi penting seperti menstimulasi pertumbuhan lengkung rahang, menjaga hubungan oklusi yang normal, dan mempunyai peranan penting dalam fungsi bicara. ${ }^{1}$ Kehilangan gigigeligi akibat pencabutan sebelum waktu erupsi dan tidak dilakukan perawatan lebih lanjut pada anak-anak dapat berakibat buruk seperti terjadinya drifting, tilting, dan malposisi dari gigi yang tetangga ataupun gigi pengganti. Masalah lain yang dapat ditimbulkan oleh terjadinya kehilangan gigi ialah masalah estetika. Ketika masalah estetika terjadi maka hal ini dapat mengakibatkan komplikasi yang lebih lanjut seperti stres dan gangguan interaksi sosial yang nantinya akan mempersulit penanganan hal tersebut. ${ }^{2}$

Terdapat banyak penyebab dilakukannya pencabutan gigi seperti adanya masalah periodontal dimana gigi yang rusak sudah tidak dapat dirawat dengan perawatan pulpa atau perawatan saluran akar. Penyebab lain dilakukannya pencabutan gigi ialah akan dilakukannya perawatan ortodonti yang mengharuskan dilakukannya pencabutan gigi. Adanya gigi persistensi, gigi yang tidak tanggal padahal telah waktunya tanggal dan menunjukkan resorpsi akar yang tidak cukup untuk terjadinya proses tanggalnya gigi, hipodonsia, dan trauma yang terus menerus terjadi atau infeksi berat pada gigi sulung adalah merupakan penyebab-penyebab lain dilakukannya pencabutan gigi sulung. ${ }^{3}$

Telah banyak penelitian yang dilakukan untuk mengetahui berbagai penyebab atau alasan dilakukannya pencabutan gigi. Odai $\mathrm{dkk}^{4}$ pada tahun 2010 melakukan penelitian terhadap 756 pencabutan gigi yang dilakukan di praktek dokter gigi di Uselu, Nigeria. Hasil penelitian mereka menunjukkan terdapat 82\% pencabutan gigi yang dilakukan disebabkan oleh karies gigi. Anyanechi dan Chukwuneke juga melakukan penelitian di Nigeria Timur pada tahun 2012 dengan jumlah total pencabutan yang dilakukan mencapai 3998 pencabutan. Hasil penelitian mereka menunjukkan dari 3998 pencabutan yang dilakukan, terdapat 55,2\% atau 2208 pencabutan dilakukan dengan alasan karies gigi $^{5}$. Penelitian ini juga pernah dilakukan oleh Pottimau E. di Puskesmas Bahu Manado pada tahun 2010 dengan jumlah total pencabutan 453. Hasil penelitian tersebut menunjukan 42,6\% pencabutan disebabkan persistensi, 31,79\% disebabkan karies gigi, 19,21\% disebabkan abses gigi, dan 6,40\% karena abses periodontal. $^{6}$ Berdasarkan keberagaman hasil penelitian diatas peneliti tertarik melakukan penelitian ini.

Peneliti akan melakukan penelitian di Pukesmas Paniki Bawah. Puskesmas Paniki Bawah merupakan puskesmas yang berada di kecamatan Mapanget. Masyarakat Manado yang bermukim di kecamatan Mapanget memanfaatkan Puskesmas Paniki Bawah sebagai sarana pengobatan dan pelayanan medis, jumlah tindakan pencabutan gigi sulung selama tahun 2012 tercatat sebanyak 122 kasus. Diharapkan dengan penelitian ini dapat diketahui karakteristik dan penyebab pencabutan gigi sulung di Puskesmas Paniki Bawah.

\section{METODE PENELITIAN}

Penelitian ini merupakan penelitian deskriptif retropektif. Tempat diadakannya penelitian ini yaitu di Puskesmas Paniki Bawah Manado. Penelitian ini telah dilaksanaka selang waktu Juni - Agustus 2014 bertempat di Puskesmas Paniki Bawah Manado. Populasi dalam penelitian ini yaitu kartu status pasien anak yang berumur 2-14 tahun yang melakukan pencabutan gigi sulungdi Poli Gigi Puskesmas Paniki bawah Manado selama tahun 2012 dengan jumlah 122 orang. Variabel penelitian ini ialah umur, jenis kelamin dan penyebab pencabutan gigi sulung.

Data yang diambil berupa data sekunder berupa kartu status pasien yang melakukan pencabutan gigi sulung di Puskesmas Paniki Bawah. Data dikumpulkan dan diolah secara manual dan disajikan dalam bentuk tabel. 


\section{HASIL PENELITIAN}

Jumlah subjek penelitian yang diperiksa selama penelitian di Puskesmas Bahu adalah berjumlah 122 kartu status pasien anak. Karakteristik subjek penelitian berdasarkan jenis kelamin dapat dilihat pada tabel 1 .

Tabel 1. Distribusi subjek penelitian berdasarkan jenis kelamin

\begin{tabular}{lll}
\hline Jenis kelamin & $\mathbf{N}$ & $\mathbf{\%}$ \\
\hline Laki-laki & 59 & 48,36 \\
Perempuan & 63 & 51,64 \\
\hline Total & 122 & 100 \\
\hline
\end{tabular}

Berdasarkan pembagian jenis kelamin dapat diketahui jumlah anak dengan jenis kelamin laki-laki terdiri dari 59 anak (48,36\%) dan subjek dengan jenis kelamin perempuan 63 anak (51,64\%). Berdasarkan pengelompokkan umur untuk mempelajari penyakit anak maka subjek penelitian dapat di karakteristikkan seperti pada Tabel 2.

Tabel 2. Distribusi subjek penelitian berdasarkan pengelompokan umur

\begin{tabular}{|c|c|c|c|c|c|c|c|c|c|c|c|c|c|}
\hline & & & & & & & \\
\hline \multirow{5}{*}{$\begin{array}{c}\text { Tabel } 2 . \\
\text { berdasarkan } \\
\begin{array}{c}\text { Pengelompokan } \\
\text { usia (tahun) }\end{array}\end{array}$} & \multirow{3}{*}{\multicolumn{2}{|c|}{$\begin{array}{l}\text { Distribusi } \\
\text { engelompo }\end{array}$}} & \multirow{3}{*}{\multicolumn{2}{|c|}{$\begin{array}{l}\text { subjek } \\
\text { n umur }\end{array}$}} & \multirow{3}{*}{\multicolumn{2}{|c|}{ penelitian }} & \multicolumn{5}{|c|}{ Jenis kelamin } & \multirow{3}{*}{$\begin{array}{l}\text { Total } \\
\text { n }\end{array}$} & \multirow{3}{*}{$\%$} \\
\hline & & & & & & & \multirow{4}{*}{$\begin{array}{l}\text { Penyebab } \\
\text { Karies }\end{array}$} & \multicolumn{2}{|c|}{ Laki-laki } & \multicolumn{2}{|c|}{ Perempuan } & & \\
\hline & & & & & & & & \multirow{3}{*}{$\frac{\mathbf{n}}{32}$} & \multirow{3}{*}{$\begin{array}{c}\% \\
26,22\end{array}$} & \multirow{3}{*}{$\frac{\mathbf{n}}{38}$} & \multirow{3}{*}{$\begin{array}{r}\% \\
31,15\end{array}$} & & \\
\hline & \multicolumn{2}{|c|}{ Laki-laki } & lamin & & & \multirow{2}{*}{ tal $\%$} & & & & & & \multirow{2}{*}{70} & \multirow{2}{*}{57,37} \\
\hline & $\begin{array}{l}\mathbf{L} \\
\mathbf{n}\end{array}$ & $\begin{array}{r}\text { i-laki } \\
\% \\
\end{array}$ & \multicolumn{2}{|c|}{ Perempuan } & $\mathbf{n}$ & & & & & & & & \\
\hline $2-4$ & 0 & 0 & 1 & 0,81 & 1 & 0,81 & Mobilitas & 21 & 17,21 & 17 & 13,93 & 38 & 31,14 \\
\hline 5-9 & 53 & 43,44 & 52 & 42,62 & 105 & 86,06 & \multirow[b]{2}{*}{ Persistensi } & \multirow[b]{2}{*}{6} & \multirow[b]{2}{*}{4,93} & \multirow[b]{2}{*}{8} & \multirow[b]{2}{*}{6,56} & \multirow[b]{2}{*}{14} & \multirow[b]{2}{*}{11,49} \\
\hline $10-14$ & 6 & 4,92 & 10 & 8,21 & 16 & 13,13 & & & & & & & \\
\hline Total & 59 & 48,36 & 63 & 51,64 & 122 & 100 & Total & 59 & 48,36 & 63 & 51,64 & 122 & 100 \\
\hline
\end{tabular}

Data di atas menunjukkan bahwa karakteristik subjek penelitian berdasarkan pengelompokkan umur yaitu usia 2-4 tahun terdapat 1 anak $(0,81 \%)$, usia 5-9 tahun terdapat 105 anak (86,06\%) dengan jumlah laki-laki sebanyak 53 anak $(43,44 \%)$ dan perempuan sebanyak 52 anak (42,62\%), sedangkan usia 10-14 tahun terdapat 16 anak (13,13\%) dengan jumlah laki-laki sebanyak 6 anak (4,92\%) dan perempuan sebanyak 10 anak (8,21\%). Data ini juga menunjukkan bahwa sampel penelitian terbanyak yaitu pada anak dengan interval usia 5-9 tahun dengan total 105 (86,06\%) anak sedangkan yang paling sedikit yaitu 24 tahun dengan jumlah 1 anak (0,81\%).
Data di atas menunjukkan bahwa penyebab pencabutan gigi yang dilakukan di Puskesmas Paniki Bawah terbagi atas tiga penyebab yaitu karies gigi, mobilitas, dan persistensi gigi. Dari ketiga penyebab tersebut, karies gigi merupakan penyebab terbanyak dengan total 70 pencabutan gigi ( $57,37 \%$ ) terbagi atas 32 pada anak laki-laki (26,22\%) dan 38 pencabutan (31,15\%) pada anak perempuan. Penyebab lainnya yaitu mobilitas gigi dengan total pencabutan 38 gigi $(31,14 \%)$ dengan 21 pencabutan $(17,21 \%)$ pada anak laki-laki dan 17 pencabutan (13,93\%) pada anak perempuan, sedangkan sisanya disebabkan oleh persistensi gigi sebanyak 14 gigi (11,49\%) dengan 6 pencabutan (4,93\%) pada anak laki-laki dan 8 pencabutan (6,56\%) pada anak perempuan.

Tabel 3. Distribusi subjek penelitian berdasarkan penyebab pencabutan gigi

\section{BAHASAN}

Berdasarkan karakteristik usia diketahui bahwa dari total 122 gigi yang dicabut pada penelitian ini, hanya terdapat 13 pencabutan gigi yang terdiri dari 1 pencabutan gigi pada anak dengan usia 4 tahun dan 12 gigi dengan usia 5 tahun yang dicabut bukan pada usia normal erupsi gigi permanen yang dimulai dari umur 6 tahun. $^{7}$ Hal ini menunjukkan berdasarkan karakteristik usia, total 109 gigi (89,34\%) yang dicabut pada penelitian ini berada dalam waktu normal erupsi gigi permanen. Namun penelitian ini tidak meneliti tentang gigi apa yang dicabut sehingga terdapat kemungkinan gigi yang dicabut merupakan 
gigi yang belum waktunya tanggal.

Berdasarkan jenis kelamin, total anak laki-laki berjumlah 59 (48,36\%) dan anak perempuan berjumlah 63 anak (51,64\%). Lebih banyaknya anak perempuan disini dapat disebabkan oleh berbagai hal seperti pertumbuhan pada anak perempuan yang lebih cepat dibandingkan anak laki-laki atau jumlah populasi anak perempuan dan laki-laki pada suatu daerah. Dalam penelitian yang dilakukan oleh Tamba S pada tahun 2010 dituliskan bahwa erupsi gigi pada anak perempuan lebih cepat dibandingkan pada anak laki-laki. ${ }^{8}$ Dalam penelitian yang lain, Hang $\mathrm{J}$ juga menyebutkan bahwa erupsi anak perempuan lebih cepat dibandingkan anak laki-laki. $^{9}$

Hasil penelitian ini memperlihatkan bahwa penyebab pencabutan gigi pada anak di Puskesmas Paniki Bawah adalah karies gigi dengan total 70 gigi dari 122 gigi yang dicabut atau 57,37\% diikuti oleh persistensi sebanyak 38 gigi $(31,14 \%)$ dan sebanyak 14 gigi $(11,49 \%)$ disebabkan oleh mobilitas gigi. Karies gigi yang merupakan penyebab utama pencabutan gigi pada penelitian ini merupakan penyakit infeksi gigi yang paling sering ditemukan pada masyarakat dan dapat ditemukan pada anak usia dini. ${ }^{10}$ Mohamad S menuliskan bahwa terdapat 90\% kasus karies yang ditemukan pada pasien anak yang datang ke klinik Pedodonsia Fakultas Kedokteran Gigi Universitas Airlangga. Nilai yang sama juga ditemukan di Jakarta. Prevalensi karies gigi pada anak balita di Malaysia juga tergolong tinggi dengan angka 87,1\%. American Academy of Paediatrics menemukan lebih dari 40\% anak balita di Amerika Serikat mengalami karies pada saat memasuki TK. Sementara itu, di Kota Zagreb Republik Kroasia, anak balita yang mengalami karies mencapai 30\%. Semua penelitian tersebut menunjukkan bahwa karies gigi merupakan penyakit gigi yang telah menyerang sejak anak usia dini sehingga besar kemungkinan jika karies gigi tidak dirawat sedini mungkin dapat menyebabkan dilakukannya pencabutan pada gigi tersebut.
Penelitian yang dilakukan oleh Mohammed AG yang meneliti penyebab dilakukannya pencabutan gigi pada anak usia 3-6 tahun di kota Mosul menunjukkan bahwa dari 130 anak yang diteliti pada penelitian tersebut terdapat 99 anak (60,7\%) yang mengalami pencabutan gigi yang disebabkan oleh karies gigi. ${ }^{1}$ Hasil yang tidak jauh berbeda juga ditemukan oleh Nsour HF yang meneliti 250 anak yang berusia 3-6 tahun yang juga mengalami pencabutan gigi. Terdapat 142 (57\%) pencabutan gigi disebabkan karies gigi. ${ }^{11}$ Kedua hasil penelitian tersebut semakin mengukuhkan karies gigi merupakan faktor utama penyebab pencabutan gigi pada anak.

Penyebab pencabutan gigi lainnya yaitu mobilitas dan persistensi gigi juga menjadi faktor penyebab dicabutnya gigi pada anak. Penelitian yang dilakukan oleh Mohammed dan Nsour juga menunjukkan bahwa mobilitas dan persistensi gigi juga merupakan salah satu penyebab dicabutnya gigi pada anak. Pada penelitian yang dilakukan oleh Mohammed ditemukan 20 gigi dari total 130 gigi yang dicabut disebabkan oleh mobilitas gigi (12,3\%) sedangkan terdapat 14 gigi (8,6\%) untuk persistensi gigi. Penelitian yang dilakukan Nsour HF juga tidak jauh berbeda dimana terdapat 29 gigi (12\%) dicabut karena mobilitas gigi dan 20 gigi (8\%) karena persistensi gigi. ${ }^{11,12}$

Mobilitas disini merupakan kegoyangan gigi yang normal terjadi pada anak yaitu kegoyangan gigi yang terjadi disebabkan gigi sudah waktunya tanggal. Mobilitas gigi disini disebabkan karena terjadinya resorpsi pada akar yang merupakan proses fisiologis normal dari gigi desidui. ${ }^{13}$ Persistensi gigi juga merupakan penyebab pencabutan gigi pada anak. Orang tua biasanya akan datang ke dokter gigi jika melihat gigi pengganti sudah muncul. Bahkan untuk orang tua yang biasanya "berani" mencabut gigi anaknya sendiri akan kebingungan bahkan takut untuk melakukan pencabutan gigi sendiri karena biasanya gigi pengganti akan erupsi dari arah lingual atau palatal 
sehingga dianggap gigi pengganti tersebut merupakan gigi yang mengganggu atau tidak dalam keadaan normal. Dalam keadaan seperti ini, para orang tua biasanya akan mendatangi dokter untuk melakukan pencabutan gigi pada anak mereka.

\section{SIMPULAN}

Berdasarkan hasil penelitian dapat disimpulkan bahwa:

1. Pencabutan gigi sulung di Puskesmas Paniki Bawah Manado pada bulan Januari 2012 sampai Desember 2012 terbanyak pada usia 5-9 tahun.

2. Berdasarkan jenis kelamin, perempuan lebih banyak daripada laki-laki.

3. Berdasarkan penyebab pencabutan gigi, karies gigi merupakan penyebab terbanyak, diikuti mobilitas dan persistensi.

\section{SARAN}

1. Bagi pemerintah diharapkan dapat mengoptimalkan upaya pencegahan dan penanggulangan masalah kesehatan gigi dan mulut yang terjadi pada anak-anak dan penyediaan alat-alat yang belum tersedia di Poli Gigi Puskesmas Paniki Bawah Manado.

2. Bagi masyarakat diharapkan dapat menggunakan fasilitas Poli Gigi di Puskesmas Paniki Bawah sehingga dapat meningkatkan status kebersihan gigi dan mulut.

\section{DAFTAR PUSTAKA}

1. Mohammed AG. Causes of primary and permanent teeth extraction in children aged 3-12 years in mosul city. AlRafidain Dent. J. 2008; 8 (2): 24S-29S.

2. Adekoya-Sofowora CA. Traumatized anterior teeth in children: a review of the literature. J Niger Med. 2001; 10(4): 151-157
3. Bjerklin $\mathbf{K}$, Bennet $\mathbf{J}$. the long term survival of second primary molars in subjects with agenesis of premolars. $\mathrm{J}$ Eur of orthod. 2000; 22: 245-255

4. Odai CD, Azodo CC, Ezeja EB, Ebuekwe ON. Reason for Exodontia in rural Nigerian children. Department periodontitics Univrsity Teaching Hospital, Benin Nigeria. 2010; 33(132): 19-24.

5. Anyanechi C, Chukwuneke F. Survey of the reasons for dental extraction in eastern Nigeria.Ann Med Health Sci Res. 2012 Jul;2(2):129-33

6. Pottimau E. Gambaran pencabutan gigi sulung di puskesmas bahu pada tahun 2010. Skripsi. Manado: Universitas Sam Ratulangi. 2011

7. McDonald RE, Avery DR, Dean JA. Dentistry for the child and adolescent. $8^{\text {th }}$ Ed. Missouri: Mosby; 2004.

8. Tamba S. Waktu erupsi gigi permanen ditinjau dari usia kronologis pada anak usia 6 sampai 12 tahun di sd st Antonius $\mathrm{v}$ medan. Skripsi. USU :Medan; 2010.

9. Pola erupsi gigi permanen pada anak etnis tionghoa sd perguruan buddhis bodhicitta. Skripsi. USU :Medan; 2010.

10. Mohamad SSB. Karies gigi pada anak usia 20-40 bulan dengan kelahiran prematur di rsu pirngadi medan. Skripsi. USU :Medan;2011

11. Mohammed AG. Causes of primary and permanent teeth extraction in children aged 3-12 years in mosul city. Alrafidain Dent. J. 2008; 8(2): 24S-29S

12. Nsour HF, Masarweh NA. Reasons for extraction of primary teeth in Jordan-a study. Pakistan Oral \& Dent. J. 2013; 33(2)

13. Harokopakis-hajishengallis E. Physiologic root resorption in primary teeth: molecular and histological events. Journal of Oral Science: 49(1):1-12. 2007. 